\title{
Real refractive indices and volatility of secondary organic aerosol generated from photooxidation and ozonolysis of limonene, $\alpha$-pinene and toluene
}

\author{
H. Kim ${ }^{1, *}$ and S. E. Paulson ${ }^{1}$ \\ ${ }^{1}$ University of California at Los Angeles, Los Angeles, California, USA \\ * now at: University of California at Davis, Davis, California, USA \\ Correspondence to: S. E. Paulson (paulson@atmos.ucla.edu)
}

Received: 18 December 2012 - Published in Atmos. Chem. Phys. Discuss.: 21 January 2013

Revised: 28 May 2013 - Accepted: 4 July 2013 - Published: 9 August 2013

\begin{abstract}
Thermodenuding particles can provide insights into aerosol composition and may be a way to create particles in laboratory chambers that better mimic the atmosphere. The relative volatility of secondary organic aerosol (SOA) was investigated by evaporating organics from the particles using a thermodenuder (TD) at temperatures between $\sim 60$ and $100^{\circ} \mathrm{C}$. Volatility was influenced by the parent hydrocarbon, oxidation chemistry and relative humidity (RH). For SOA generated from ozonolysis, limonene had lower volatility than $\alpha$-pinene, and $\mathrm{OH}$ scavengers had no influence on volatility. For photooxidation, $\alpha$-pinene SOA was slightly more volatile than limonene SOA. Increasing RH also modestly increased volatility, while toluene SOA was unaffected by heating to $98^{\circ} \mathrm{C}$. For both $\alpha$-pinene and limonene, the concentration of $\mathrm{NO}_{\mathrm{x}}$ and the $\mathrm{HC} / \mathrm{NO}_{\mathrm{x}}$ ratio had no discernible effect on SOA volatility. Refractive indices for the original and denuded particles were retrieved from polar nephelometer measurements using parallel and perpendicular polarized $532 \mathrm{~nm}$ light. Retrievals were performed with a genetic algorithm method using Mie-Lorenz scattering theory and measured particle size distributions. Retrieved refractive indices for the SOA before thermodenuding varied between 1.35 and 1.61 depending on several factors, including parent hydrocarbon, oxidation chemistry, and SOA generation temperature. For high $\mathrm{NO}_{\mathrm{x}} \mathrm{SOA}$, as particles shrink, their refractive index returns to the value of the corresponding size particles before heating (limonene) or slightly higher ( $\alpha$-pinene). For low $\mathrm{NO}_{\mathrm{x}}$ however, the resulting refractive index is $0.05 \pm 0.02$ lower than the corresponding size undenuded particles. Additionally, for $\alpha$ -
\end{abstract}

pinene SOA from ozonolysis with $\mathrm{OH}$ radical scavenger, resulting refractive indices were higher by about 0.03 after heating. Consistent with no change in size, refractive indices of toluene SOA were unaffected by heating. Finally, refractive index data available to date are reviewed, leading to the suggestion that the most representative values for $m_{\mathrm{r}}$ at $\lambda=532 \mathrm{~nm}$ for biogenic and anthropogenic SOA are 1.44 and 1.55 , respectively.

\section{Introduction}

Atmospheric aerosols play an important role in determining direct radiative transfer by scattering and absorbing solar radiation. Refractive indices are also necessary to determine the optical parameters relevant to radiative transfer such as single scatter albedo, asymmetry factor and specific absorption using Mie-Lorenz theory. Additionally, reliable phase function and polarization information is essential for the interpretation of satellite and aircraft measurements to infer aerosol optical depth, size and single scatter albedo (Mishchenko, 2007).

Organic compounds constitute $20-70 \%$ of aerosol mass in the lower troposphere depending on space and time, of which roughly $70-90 \%$ is contributed by secondary organic aerosols (SOAs) (Hallquist et al., 2009). Their contribution to the global radiation balance depends on their production and loss rates and size distribution, their interactions with other radiatively important atmospheric constituents (via the "indirect and semi-direct" effects), and on their direct interactions 
with insolation and upwelling terrestrial infrared radiation. The radiative properties of these ubiquitous SOA particles are poorly understood (Kanakidou et al., 2005). This is due to the chemical and physical complexity of the organic aerosols as well as the limited number of measurements available.

Recently, several methods to measure or estimate optical properties of aerosols (rather than bulk materials) have been developed, and some laboratory studies have begun to derive refractive indices for SOA (Lambe et al., 2013; Barkey et al., 2007; Kim et al., 2010, 2012; Lang-Yona et al., 2010; Nakayama et al., 2010, 2013; Schnaiter et al., 2005; Yu et al., 2008). These studies showed that $m_{\mathrm{r}}$ 's span a reasonably wide range, from 1.35 to 1.6 , likely depending primarily on the chemical composition, which in turn is determined by precursors, oxidation chemistry, temperature, diameter and aerosol mass concentration. At this point it is not yet clear which values are most representative of ambient aerosols.

Many currently available optical measurements of SOA have been performed on particles generated in environmental chambers or flow tubes (see references in Hallquist et al., 2009; Kim et al., 2012), often at unrealistically high aerosol mass concentrations. Thus, while ambient species are believed to be comprised of primarily low volatility species, chamber-generated SOAs contain species with a wide range of volatilities, potentially reducing the atmospheric relevance of laboratory-generated SOAs. The thermodenuder (TD) is a tool that can be used to help unravel some aspects of volatility, and it has been applied in a number of recent laboratory and field studies (Cappa and Wilson, 2011; Huffman et al., 2009; Jonsson et al., 2007; Kostenidou et al., 2009; Lee et al., 2011). Chamber experiments produce aerosols with higher volatility material because they are commonly run at high precursor concentration. While it might seem that this problem could be solved by lowering the precursor concentration, this approach introduces a different problem, namely that low volatility species now have much more opportunity to deposit on the chamber walls (Matsunaga and Ziemann, 2010), depleting them from the aerosol phase. By generating aerosols at higher concentration and thermodenuding them, we may obtain aerosols with the full range of volatilities, and possibly obtain more atmospherically relevant lower volatility species. In a typical TD, aerosols are heated at a fixed temperature for a specific period of time, evaporating the high volatility compounds from the particles. Following the heating section, the particles pass through an activated carbon denuder to remove volatilized gas phase organic species to minimize recondensation on the particles as they cool.

Several TD studies to date have provided insights into aerosol volatility. Jonsson et al. (2007) showed the impact of relative humidity $(\mathrm{RH}), \mathrm{OH}$ scavenger and temperature of SOA formation on the volatility of limonene and $\alpha$-pinene SOA. Lee et al. (2011) showed that with sufficient residence time, $\alpha$-pinene, $\beta$-pinene and limonene SOA can be almost completely evaporated at $\sim 90^{\circ} \mathrm{C}$. They also found that the concentrations of the precursor, and $\mathrm{NO}_{\mathrm{x}}$ as well as
RH each influenced SOA volatility. Several recent studies have related SOA volatility and chemical composition, and provide a somewhat inconsistent precursor-specific picture of the effect of thermodenuding on chamber particle composition and comparability to ambient particles. By combining TD and aerosol mass spectrometer (AMS) measurements, Kostenidou et al. (2009) showed that the lower volatility components of $\alpha$ - and $\beta$-pinene ozonolysis SOA that remained after heating up to $90^{\circ} \mathrm{C}$ had similar chemical composition as ambient aerosol from Pittsburgh, PA (USA), but did not find this similarity for limonene ozonolysis SOA. Recently, Cappa and Wilson (2011) characterized the SOA from the $\alpha$-pinene-ozone reaction without scavenger using vacuum ultraviolet photoionization $\mathrm{MS}$ as the particles were heated to $170^{\circ} \mathrm{C}$. The chemical composition of SOA was not changed by heating, although the aerosol mass concentration was reduced due to evaporation.

In this study we use a TD to evaporate the high volatility components from SOA generated in a smog chamber, and retrieve their refractive indices in an effort to obtain the optical properties of SOA similar to ambient aerosols. We investigate volatility and related $m_{\mathrm{r}}$ 's for SOA generated from $\alpha$-pinene, limonene and toluene using several different oxidation chemistries (reaction with $\mathrm{O}_{3}$ with and without scavenger, and photooxidation at different $\mathrm{HC} / \mathrm{NO}_{\mathrm{x}}$ ratios). $\alpha$ Pinene and limonene are representative biogenic hydrocarbons, accounting for approximately $25 \%$ and $16 \%$ of global monoterpene emissions, respectively, and toluene is typically the most abundant aromatic compound emitted globally (Kanakidou et al., 2005). For dark ozone reactions of unsaturated hydrocarbons, conditions can be adjusted so that organics can react either solely with $\mathrm{O}_{3}$ or with both $\mathrm{O}_{3}$ and OH (Paulson et al., 1997). The chemical composition of SOA generated photochemically varies depending on the branching of $\mathrm{RO}_{2}$ reactions with $\mathrm{HO}_{2} / \mathrm{RO}_{2}$ vs. $\mathrm{NO}$, which is in turn controlled by the $\mathrm{HC} / \mathrm{NO}_{\mathrm{x}}$ ratio. Angular scattering, including polarization, was measured with a second-generation polar nephelometer (Kim et al., 2010, 2012). A genetic algorithm (GA) approach was used to retrieve refractive indices from the polar nephelometer (PN) angular scattering data from the PN (Barkey et al., 2007).

\section{Experiment}

\subsection{Secondary organic aerosol generation}

Experiments were performed in a $24 \mathrm{~m}^{3}$ Teflon chamber constructed on the roof of the Math Sciences Building at UCLA. The chamber is described in detail by Chung et al. (2008). Air is supplied to the chamber by two 33-gallon oil-free portable air compressors (Craftsman) after passing through a series of packed bed scrubbers filled with Purafil Triple Blend (Purafil Inc.), activated charcoal, and HEPA capsule filters (Gelman). The scrubbed air had $<5$ particles $\mathrm{cm}^{-3}$, 
Table 1. Initial conditions, temperatures, relative humidities and results of the photooxidation experiments.

\begin{tabular}{|c|c|c|c|c|c|c|c|c|c|c|c|}
\hline \multirow[b]{2}{*}{ Expt. } & \multicolumn{4}{|c|}{ Initial conditions } & \multirow[b]{2}{*}{$\begin{array}{l}\text { Temp } \\
\left({ }^{\circ} \mathrm{C}\right)^{1}\end{array}$} & \multirow[b]{2}{*}{$\begin{array}{r}\mathrm{RH} \\
(\%)^{1}\end{array}$} & \multicolumn{5}{|c|}{ Results } \\
\hline & $\begin{array}{l}\text { Hydrocar- } \\
\text { bon }\end{array}$ & $\begin{array}{r}\mathrm{HC} \\
(\mathrm{ppb})\end{array}$ & $\begin{array}{l}\mathrm{NO}_{\mathrm{x}} \\
(\mathrm{ppb})\end{array}$ & $\begin{array}{r}\mathrm{HC} / \mathrm{NO}_{\mathrm{x}} \\
\left(\mathrm{ppbC} \mathrm{ppb}^{-1}\right)\end{array}$ & & & $\begin{array}{l}\Delta \mathrm{HC} \\
(\mathrm{ppb})\end{array}$ & $\begin{array}{l}\# \text { density } \\
\left(\# / \mathrm{cm}^{3}\right)^{2}\end{array}$ & $\begin{array}{r}\text { Size mode } \\
(\mathrm{nm})^{2}\end{array}$ & $\begin{array}{r}\text { Mass }^{3} \\
\left(\mu \mathrm{g} \mathrm{m}^{-3}\right)\end{array}$ & $\begin{array}{r}\text { Yield }^{4} \\
(\%)\end{array}$ \\
\hline 18 Aug & $\alpha$-pinene & 150 & 230 & 6.5 & $39-33$ & $17-23$ & 150 & 255 & 573 & $9-44$ & 5.9 \\
\hline 22 Aug & $\alpha$-pinene & 152 & 110 & 14 & $37-39-33$ & $20-17-24$ & 148 & 599 & 514 & $19-103$ & 14 \\
\hline $21 \mathrm{Sep}$ & $\alpha$-pinene & 142 & 50 & 28 & $33-36$ & $28-25$ & 138 & 3740 & 359 & $18-107$ & 16 \\
\hline 26 Aug & $\alpha$-pinene & 153 & 47 & 33 & $39-46-42$ & $18-13-15$ & 130 & 1540 & 429 & $22-118$ & 17 \\
\hline 8 Aug & Limonene & 208 & 300 & 6.9 & $37-32$ & $16-20$ & 206 & 3692 & 429 & $96-287$ & 35 \\
\hline 4 Aug & Limonene & 140 & 98 & 14 & $36-40$ & $15-18$ & 138 & 1833 & 400 & $34-195$ & 35 \\
\hline $16 \mathrm{Nov}$ & Limonene & 157 & 120 & 13 & $24-26$ & $38-34$ & 144 & 3523 & 359 & $32-214$ & 37 \\
\hline 2 Aug & Limonene & 130 & 41 & 32 & $38-42$ & $15-18$ & 128 & 2470 & 300 & $11-219$ & 43 \\
\hline 16 Aug & Limonene & 130 & 39 & 33 & $35-39-34$ & $22-18-24$ & 130 & 2795 & 372 & $14-275$ & 47 \\
\hline 29 Aug & Toluene & 2760 & 1350 & 15 & $42-35$ & $18-26$ & 990 & 5460 & 445 & $74-365$ & 4.0 \\
\hline 24 Aug & Toluene & 2770 & 620 & 32 & $39-35$ & $20-24$ & 820 & 3090 & 429 & $100-320$ & 11 \\
\hline
\end{tabular}

\footnotetext{
${ }^{1}$ Initial and final temperature and relative humidity. ${ }^{2}$ Final aerosol number concentration and size mode. These values have not been adjusted for wall losses.

${ }^{3}$ Mass concentration in the chamber was determined from the SMPS-measured size distribution in the chamber over the period for which meaningful PN measurements were made. Particle density was assumed to be $1.2 \mathrm{~g} \mathrm{~cm}^{-3}$ for $\alpha$-pinene, $1.25 \mathrm{~g} \mathrm{~cm}^{-3}$ for limonene and $1.24 \mathrm{~g} \mathrm{~cm}^{-3}$ for toluene. ${ }^{4} \mathrm{Calculated} \mathrm{from}$ peak measured aerosol mass and the corresponding quantity of reacted hydrocarbon, corrected for wall losses. Because of the uncertainties in the measurement from (GC) $( \pm 3 \%)$ and measurement of SMPS $( \pm 10 \%)$, yields are uncertain to $\pm 10 \%$.
}

Table 2. Initial conditions, temperatures, relative humidities and results of the ozonolysis experiment.

\begin{tabular}{llrrrrrrrrr}
\hline \multicolumn{1}{c}{ Initial conditions } \\
\hline Run & Hydrocarbon & $\begin{array}{r}\mathrm{HC} \\
(\mathrm{ppb})\end{array}$ & $\begin{array}{r}\text { Ozone } \\
(\mathrm{ppb})\end{array}$ & $\begin{array}{r}\text { Temp } \\
\left({ }^{\circ} \mathrm{C}\right)\end{array}$ & $\begin{array}{r}\text { RH } \\
(\%)\end{array}$ & $\begin{array}{r}\Delta \mathrm{HC} \\
(\mathrm{ppb})\end{array}$ & $\begin{array}{r}\# \text { density } \\
\left(\# / \mathrm{cm}^{3}\right)\end{array}$ & $\begin{array}{r}\text { Size mode }^{2} \\
(\mathrm{~nm})\end{array}$ & $\begin{array}{r}\text { Mass }^{3} \\
\left(\mu \mathrm{m} \mathrm{m}^{-3}\right)\end{array}$ & $\begin{array}{r}\text { Yield }^{4} \\
(\%)\end{array}$ \\
\hline 20 Aug & $\alpha$-pinene & 143 & 500 & $26-27$ & $33-31$ & 107 & 1080 & 478 & $28-230$ & 46 \\
$18 \mathrm{Oct}$ & $\alpha$-pinene & 150 & 500 & $23-26$ & $34-36$ & 130 & 2780 & 414 & $39-271$ & 44 \\
29 Sep & $\alpha$-pinene & 170 & 500 & $23-28$ & $38-30$ & 156 & 5820 & 322 & $37-271$ & 40 \\
$10 \mathrm{Nov}$ & $\alpha$-pinene & 160 & 500 & $23-22$ & $24-25$ & 160 & 25600 & 217 & $71-349$ & 45 \\
$18 \mathrm{Nov}$ & $\alpha$-pinene & 126 & 500 & $18-20$ & $43-39$ & 118 & 17400 & 233 & $34-215$ & 39 \\
31 Aug & Limonene & 167 & 500 & $25-27$ & $38-35$ & 167 & 1280 & 300 & $98-579$ & 78 \\
23 Nov & Limonene & 198 & 500 & $20-22$ & $41-35$ & 198 & 33000 & 209 & $83-614$ & 72 \\
24 Oct & Limonene & 150 & 500 & $21-23$ & $42-40$ & 150 & 18800 & 250 & $96-454$ & 72 \\
\hline
\end{tabular}

$1,2,3,4$ Same as footnotes 1-4 in Table 1 above. ${ }^{5}$ Cyclohexane was added in 50-fold excess compared to the hydrocarbon to suppress reactions of $\mathrm{OH}$ with the $\alpha$-pinene and limonene.

and $\mathrm{NO}_{\mathrm{x}}$ (Thermo Electron model 14B/E), $\mathrm{O}_{3}$ (Dasibi 1001RS), and VOC (GC, HP 5890-II) levels below the $1 \mathrm{ppb}$ detection limits. Access to the inside of the chamber is provided by custom Teflon sampling ports. Teflon (gasses) and copper (particles) sampling lines extend $20 \mathrm{~cm}$ into the chamber and withdraw samples at $0.6\left(\mathrm{NO}_{\mathrm{x}}\right)$ and $2\left(\mathrm{O}_{3}\right.$ and organics) $\mathrm{L} \mathrm{min}^{-1}$. Between experiments, a vent is opened and the chamber is flushed with clean air for $10 \mathrm{~h}$ in full sun in preparation for the next experiment.

Tables 1 and 2 show initial conditions and summary statistics for 20 experiments. For photooxidation experiments, the chamber, covered with a black tarpaulin (supported on a frame above the chamber), was half-filled with purified air. At this point, gas phase reagents such as NO (Scott Specialty Gasses) and propene (Aldrich, as a photochemical initiator for toluene) were added. Later, the SOA precursor hydrocarbon liquid was evaporated into the air stream filling the chamber. Limonene (Aldrich, 99.8\%), $\alpha$-pinene (Fluka, $98.5 \%$ ) and toluene (Aldrich, 99.8\%) were used as received. The chamber contents were allowed to mix for about $40 \mathrm{~min}$. Once the gas chromatograph returned two measurements within $2 \%$ of one another, the tarps were removed and photochemistry initiated. The overall oxidation time was $4-5 \mathrm{~h}$ for limonene and $\alpha$-pinene, and 5-6h for toluene.

For ozone experiments, the hydrocarbon(s) (precursor with or without cyclohexane) for selected experiments was (were) injected into the half-full chamber. After the chamber contents were well mixed, excess ozone was generated by flowing pure oxygen $\left(0.5 \mathrm{~L} \mathrm{~min}^{-1}\right)$ through a mercury lamp $\mathrm{O}_{3}$ generator (Jelight, model 600) and introduced into the chamber. In order to minimize inhomogeneities, the chamber was mixed manually while ozone was injected. 


\section{Thermodenuder}

The thermodenuder (TD) was constructed in-house using the design of Lee et al. (2011). The TD consisted of a variable temperature heated section $(L=55 \mathrm{~cm}$, inner tube $D=3.5 \mathrm{~cm}$, outer tube $D=6 \mathrm{~cm}$ ) followed by an activated carbon denuder section $(L=45 \mathrm{~cm}$, inner mesh $D=3.5 \mathrm{~cm}$, outer tube $D=6 \mathrm{~cm}$ ). Temperature was controlled with heating tape wrapped on outer tube of heating sections. The space in between inner tube/mesh and outer tube was filled with sand (heating section) and activated carbon (denuding section), respectively. The flow rate through the TD was $1 \mathrm{~L} \mathrm{~min}-1$, corresponding to a centerline residence time of $16 \mathrm{~s}$. Measurements of volatility were made with the temperature of the heated section ranging from ambient up to $98^{\circ} \mathrm{C}$. The temperature profile was measured with a $60 \mathrm{~cm}$ long thermocouple (OMEGACLAD, KQXL-18E) positioned in the center of the heating tube. As shown on Fig. S1, the temperature reached its maximum at $27 \mathrm{~cm}$ from the entrance, and remained within $\pm 3{ }^{\circ} \mathrm{C}$ of this value to $45 \mathrm{~cm}$, after which point it began to decrease somewhat. Temperatures reported here are the maximum temperatures, measured $35 \mathrm{~cm}$ from the entrance.

For terpenes, to minimize complications created by rapidly changing particle size distributions, TD measurements were made after the mass concentration reached its maximum. Toluene nucleated late and grew slowly and continuously throughout the $6 \mathrm{~h}$ experiments, so TD measurements were initiated once rapid particle growth ceased and the particle growth rate decreased below $2 \mathrm{~nm} \mathrm{~min}{ }^{-1}$. Two or three different TD temperatures were explored between 60 and $110^{\circ} \mathrm{C}$, as experimental conditions permitted. Within this temperature range, almost all of the more volatile species should be evaporated, in principle creating particles with similar chemical composition to ambient organic aerosol (e.g., Kostenidou et al., 2009; Lee et al., 2011). It took 6$9 \mathrm{~min}$ for the TD to stabilize at a new temperature (Fig. 1a). Once the temperature was stable, the PN and scanning mobility particle sizer (SMPS) were switched to sample denuded and undenuded chamber particles every $3 \mathrm{~min}$ for about $30 \mathrm{~min}$.

\subsection{SOA characterization and experimental setup}

Aerosols were characterized with polar and integrating nephelometers, an SMPS and a microbalance. Figure S2 shows a measurement schematic; SOA are drawn either into a bypass line or through the thermodenuder and then to a 4-way value (Swagelok). The aerosol flow direction was controlled in such a way that the bypass line (original particles) is sampled by the polar nephelometer (PN, described below) while the SMPS (TSI model 3080) samples the thermodenuder line (denuded particles) or vice versa. The valve was switched every $3 \mathrm{~min}$ so that the PN and SMPS sampled original or thermodenuded particles alternately each for $3 \mathrm{~min}$ of every
6 min. Since thermodenuded and chamber particles are sampled alternately by the SMPS or PN, before and after size distribution means and standard deviations for the same type of SOA were averaged to use in retrievals of the refractive index for each point ( $3 \mathrm{~min}$ of averaged data). As measurements were made later in the experiments, after rapid growth had stopped, the phase functions and size distributions exhibited only minimal changes from one cycle to the next. Additionally, any difference between the actual size distribution and the averaged one is encompassed by the large $( \pm 30 \%)$ genetic algorithm size parameter search space.

The upgraded polar nephelometer used in this study and its calibrations are described in detail in Kim et al. (2010) and Kim et al. (2012). Every $16 \mathrm{sec}$, the PN measures light intensities scattered at 21 discrete angles by a stream of aerosols intersecting the beam of a $532 \mathrm{~nm} 1 \mathrm{~W}$ laser. A $1 / 2$ wave plate rotates the polarization plane of the incident light to be parallel or perpendicular to the measurement scattering plane. The $1 \mathrm{~L} \mathrm{~min}^{-1}$ aerosol sample flow, which intersects a $2 \times 5 \mathrm{~mm}$ beam, is confined to the center of the scattering plane by a $10 \mathrm{~L} \mathrm{~min}^{-1}$ sheath flow. The SMPS measures particle size distributions from 19 to $948 \mathrm{~nm}$ every $3 \mathrm{~min}$, and these are used to interpret the PN data as well as determine aerosol formation yields. A multiple charging correction was applied to all SMPS scans. The genetic algorithm (GA) approach used to retrieve refractive indices from the $\mathrm{PN}$ angular scattering data is described in detail in Barkey et al. (2007) and Kim et al. (2010). SOAs are accepted to be reasonably spherical, as verified in Barkey et al. (2007). The absolute error associated with the $m_{\mathrm{r}}$ retrieval above is \pm 0.03 , and the instrument has sufficient sensitivity to achieve reliable retrievals for about $20 \mu \mathrm{g} \mathrm{m}^{-3}$ of mass concentration with particles larger than about $100 \mathrm{~nm}$. All of the retrieved $m_{\mathrm{r}}$ 's had fitness values of at least 0.95 .

The integrating nephelometer (Ecotech M9003) measures scattering at $700 \mathrm{~nm}$ as well as relative humidity and temperature with $1 \mathrm{~min}$ time resolution. In order to check the SMPS mass, filter samples for gravimetric analysis were collected on pre-baked $\left(24 \mathrm{~h}\right.$ at $\left.550^{\circ} \mathrm{C}\right) 25 \mathrm{~mm}$ quartz fiber filters (Pall Life Sciences) for 10-20 min at $20 \mathrm{~L} \mathrm{~min}^{-1}$ toward the end of the experiments. Filters were allowed to be equilibrated for $24 \mathrm{~h}$ in a temperature- and humidity-controlled room before weighting using a microbalance $( \pm 1 \mu \mathrm{g}$, Sartorius). As SOA is lost to the walls of the chamber during the experiment, first-order loss coefficients varying between $0.0012 \mathrm{~min}^{-1}$ and $0.0081 \mathrm{~min}^{-1}$ (Kim et al., 2010, depending on particle size) were applied to correct wall loss of particles for yield calculations. For SOA volatility calculations, losses of SOA particle within the TD due to sedimentation, diffusion and thermophoresis were determined using $\mathrm{NaCl}$ (99\%, Sigma-Aldrich) aerosol, generated by nebulizing a $0.005 \mathrm{M} \mathrm{NaCl}$ solution (Collison spray nebulizer, BGI Inc.). Details on experiments and particle loss results are shown in the Supplement (Fig. S3). 


\section{Results and discussion}

Initial conditions and results for 20 experiments with three different precursors (limonene, $\alpha$-pinene and toluene) under five different conditions were performed: photooxidation at low $\mathrm{NO}_{\mathrm{x}}$ (initial $\mathrm{HC} / \mathrm{NO}_{\mathrm{x}}=32-33$ ), intermediate $\mathrm{NO}_{\mathrm{x}}$ $\left(\mathrm{HC} / \mathrm{NO}_{\mathrm{x}}=13-14\right)$ and high $\mathrm{NO}_{\mathrm{x}}\left(\mathrm{HC} / \mathrm{NO}_{\mathrm{x}}=6.5-6.9\right)$ and ozonolysis with and without $\mathrm{OH}$ scavenger are shown in Tables 1 and 2. Precursor concentrations ranged from 126 to $258 \mathrm{ppb}$ for the terpenes and from 2760 to $2770 \mathrm{ppb}$ for toluene, which requires higher concentrations to produce sufficient SOA mass.

\subsection{Aerosol formation yields}

For aerosol yields (aerosol mass/HC reacted, both in $\mu \mathrm{g} \mathrm{m}^{-3}$ ), SOA mass was calculated from SMPS size distributions assuming spherical particles with densities of 1.25 , 1.2 and $1.24 \mathrm{~g} \mathrm{~cm}^{-3}$ for limonene, $\alpha$-pinene and toluene, respectively (Hallquist et al., 2009; $\mathrm{Ng}$ et al., 2006, 2007). Measured particle number concentrations were corrected for size-dependent wall loss (above). Gravimetric mass measurements averaged $18 \pm 8 \%$ higher than the SMPS mass measurements, almost identical to the difference observed in our recent limonene study (17 $\pm 7 \%$, Kim et al., 2012). The gravimetric filter samples are expected to overestimate particle mass somewhat due to adsorption of gasses during sampling (Chung et al., 2008). Our yield data follow the expected trends; yields appear to be higher at lower temperatures, higher initial $\mathrm{HC} / \mathrm{NO}_{\mathrm{x}}$ ratios, and higher aerosol mass in the chamber (Hallquist et al., 2009; Kim et al., 2012). As expected, aerosol yields for limonene are significantly higher than $\alpha$-pinene (Tables 1 and 2). As expected, the higher initial hydrocarbon concentrations resulted in high aerosol mass concentrations, and the aerosol yields fall at the upper end of the literature values (Griffin et al., 1999; Kim et al., 2012; Ng et al., 2006; Saathoff et al., 2009).

\subsection{Reaction profile of a photooxidation experiment}

Figure 1 shows chamber and thermodenuded results for a typical photooxidation experiment (22 August). The experiment had initial concentrations of $152 \mathrm{ppb}$ of limonene and $110 \mathrm{ppb}$ of NO. SOA began to nucleate $84 \mathrm{~min}$ after the chamber was initially exposed to sunlight, and quickly grew to several hundred nm (Fig. 1b and c). The thermodenuder temperature was increased in three steps from 64 to $84^{\circ} \mathrm{C}$, beginning after the mass concentration had reached its maximum (Fig. 1a and b). Figure $1 \mathrm{~b}$ shows $\mathrm{NO}, \mathrm{NO}_{\mathrm{x}}, \mathrm{O}_{3}, \alpha$ pinene and aerosol mass concentration, not corrected for wall and thermodenuder losses. Figure 1c shows the evolution of particle number, mean diameter, and integrated scattering $\left(\beta_{\text {sca }}\right)$. The particles continued to grow throughout; however, particle number concentrations dropped due to coagulation and wall loss after 12:40 LT. $\beta_{\text {sca }}$ is measured from

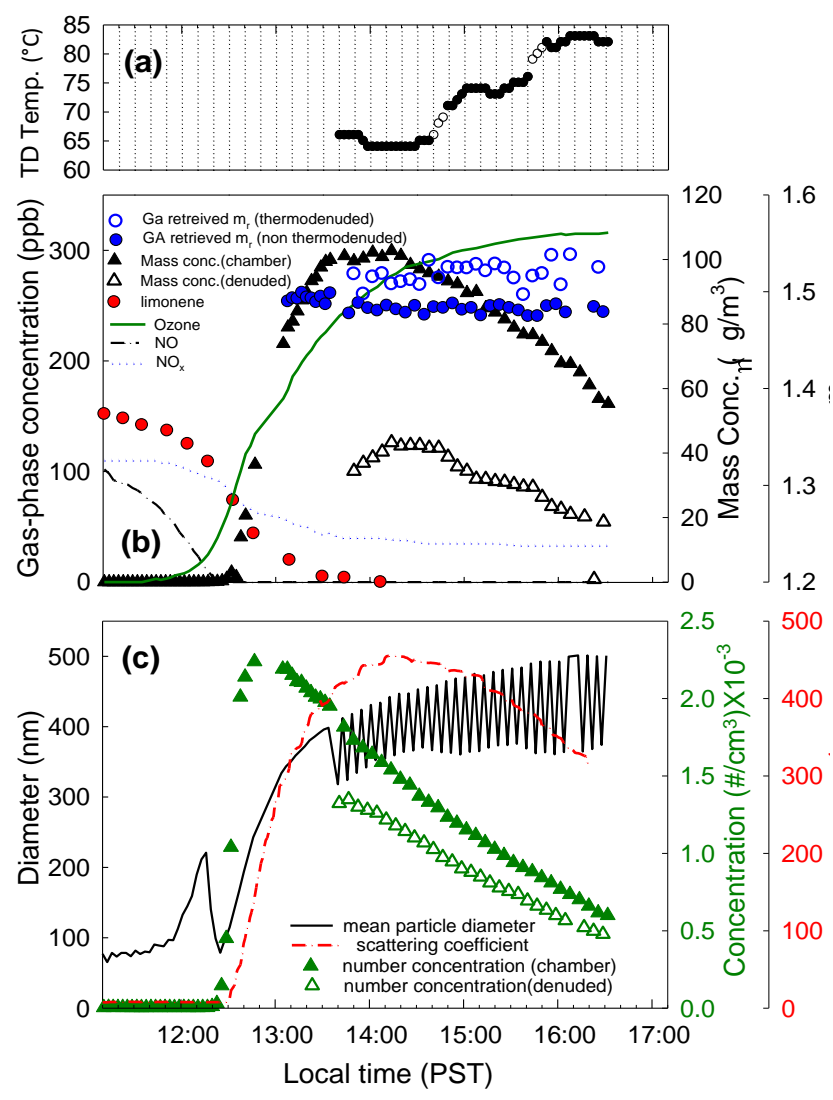

Fig. 1. Profile of the $\alpha$-pinene photooxidation experiment performed on 22 August, with initial $\alpha$-pinene, $152 \mathrm{ppb} ; \mathrm{NO}_{\mathrm{x}}, 110 \mathrm{ppb}$. (a) Temperature profile of $\mathrm{TD}$, (b) hydrocarbon, $\mathrm{NO}, \mathrm{NO}_{\mathrm{x}}, \mathrm{O}_{3}$, aerosol mass concentration and GA-determined real refractive index of SOA from chamber and thermodenuder. (c) Time evolution of SOA particle number concentrations, mean diameters of SOA from chamber and thermodenuder and scattering coefficient $\left(\beta_{\mathrm{sca}}\right)$. Each symbol (triangle, circle) has 3 min time resolution.

particles from the chamber (undenuded) and continues to increase as particle numbers drop until 14:18 LT, at which point the decrease in numbers overtakes the increases in scattering due to growing particles (Fig. 1c). Particle phase functions were first obtained when the particles had grown to about $194 \mathrm{~nm}\left(21 \mu \mathrm{g} / \mathrm{m}^{3}\right)$ at 12:40, but reliable refractive indices (fitness $>0.95$ ) were first obtained when the particles had grown to about $344 \mathrm{~nm}$ at 13:07 (because of the malfunction of SMPS for a while and re-zeroing issue with polar nephelometer). For undenuded particles, $m_{\mathrm{r}}$ decreases very slowly from when retrievals are first obtained from about 1.50 to 1.48 at the end of the experiment. We consistently observe that the refractive index changes only slowly after the initial growth phase has ended and the aerosol mass concentration has reached its peak (Barkey et al., 2007; Kim et al., 2010, 2012), suggesting that the chemical composition of the SOA changes only slowly later in the experiments. Thermodenuded particles exhibit slightly higher $m_{\mathrm{r}}$ 's at $1.51-1.54$ 

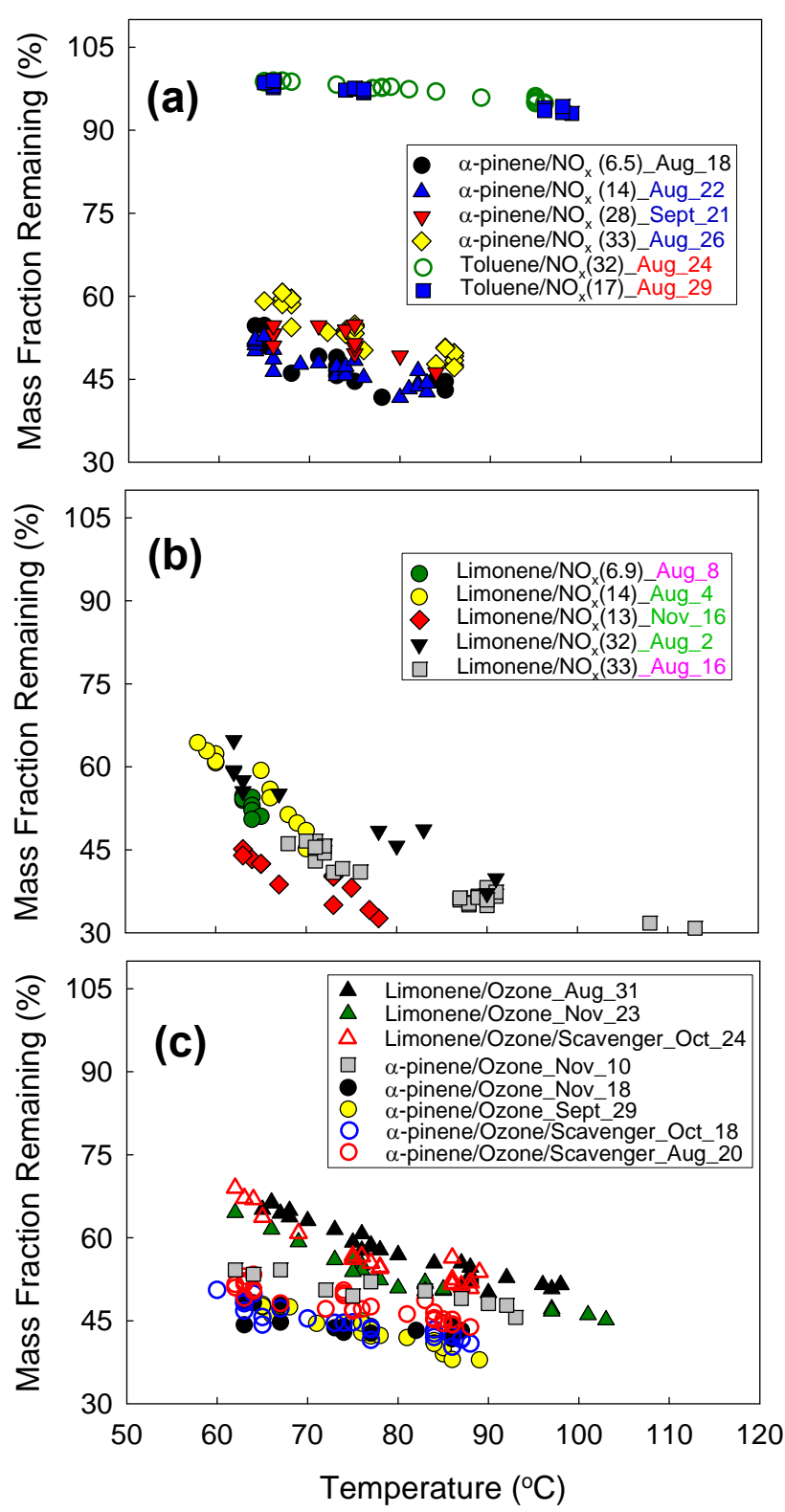

Fig. 2. Mass fraction remaining after passing through the TD as a function of TD temperature for SOA formed by photooxidation of (a) toluene and $\alpha$-pinene and (b) limonene at different $\mathrm{HC} / \mathrm{NO}_{\mathrm{x}}$ ratios, and (c) ozonolysis SOA. All data corrected for experimentally determined TD losses (Fig. S3). For photooxidation experiments, the dates in the legend are color-coded to indicate the mass concentration range prior to thermodenuding. Black: $<100 \mu \mathrm{g} \mathrm{m}^{-3}$; blue: $<120 \mu \mathrm{g} \mathrm{m}^{-3}$; green: $<220 \mu \mathrm{g} \mathrm{m}^{-3}$; pink: $<300 \mu \mathrm{g} \mathrm{m}^{-3}$; red: $>300 \mu \mathrm{g} \mathrm{m}^{-3}$.

(Fig. 1b), and particle numbers and diameters are reduced to $74-78 \%$ and $73-82 \%$ of the original values, respectively, decreasing with increasing TD temperature.

\subsection{Volatility measurements}

\subsubsection{Volatility of photooxidation SOA}

The SOA mass fraction remaining (MFR) corrected for particle losses in the TD (Fig. S3) as a function of TD temperature is shown in Fig. 2. Biogenic SOA was increasingly denuded as temperature was increased. In contrast, toluene exhibited virtually no evaporation over the range investigated.

$\alpha$-Pinene SOA MFRs were $61-42 \%$ for the range 64 $86^{\circ} \mathrm{C}$; limonene SOA MFRs were $65-31 \%$ as the temperature was increased from 58 to $113^{\circ} \mathrm{C}$. For both $\alpha$-pinene and limonene SOA, there was no evidence of an impact of the $\mathrm{HC} / \mathrm{NO}_{\mathrm{x}}$ ratio on volatility for temperatures between 60 and $85^{\circ} \mathrm{C}$. The mass concentration prior to thermodenuding (Saleh et al., 2011) also did not appear to be a factor (Fig. S6). A difference might be expected for low $\mathrm{NO}_{\mathrm{x}}$ conditions, as a significant fraction of this $\mathrm{SOA}$ is believed to consist of hydroperoxide groups from $\mathrm{RO}_{2}+\mathrm{HO}_{2}$ that are less volatile than the species (organic nitrate and other products) produced via $\mathrm{RO}_{2}+\mathrm{NO}$ at lower $\mathrm{HC} / \mathrm{NO}_{\mathrm{x}}$ (Presto et al., 2005). Lee et al. (2011) reported that the $\mathrm{HC} / \mathrm{NO}_{\mathrm{x}}$ ratio did impact $\alpha$-pinene SOA volatility between $\mathrm{HC} / \mathrm{NO}_{\mathrm{x}}=6$ and $\mathrm{NO}_{\mathrm{x}}$-free over the TD temperature range $45-60^{\circ} \mathrm{C}$, but did not observe a dependence above $60^{\circ} \mathrm{C}$, consistent with our results. Lee et al. (2011) reported no impact of $\mathrm{NO}_{\mathrm{x}}$ concentration on the volatility of limonene SOA between 25 and $100^{\circ} \mathrm{C}$, and that higher temperatures were required to evaporate the limonene almost completely than $\alpha$-pinene SOA, also in agreement with our results. The limonene SOA generated on November 16 was somewhat more volatile (by $\sim 13-15 \%$ ) than other experiments. This experiment had significantly higher RH (by 10-19\%), implying RH may have a modest effect on SOA volatility. Consistent with this result, Jonsson et al. (2007) and Lee et al. (2011) also reported moderate increases in volatility with increasing $\mathrm{RH}$, since the presence of more water in the gas phase during oxidation possibly increases the fraction of volatile material present on the particles.

\subsubsection{Volatility of SOA from ozonolysis}

$\alpha$-Pinene SOA from ozonolysis had about $15 \%$ lower MFRs than limonene ozonolysis SOA. However, this could have a contribution from the high mass concentration of particles prior to denuding between the experiments (Fig. S6, Saleh et al., 2011). For both terpenes, addition of a scavenger did not have a discernible effect (Fig. 2c). This is in agreement with Jonsson et al. (2007), who reported no differences at the moderate temperatures used here, although they did find a difference above $150^{\circ} \mathrm{C}$. SOA generated in the 10 November experiment was somewhat less volatile (by $\sim 10 \%$ ) than SOA from other $\alpha$-pinene/ozone/no scavenger experiments (Table 2 ). This experiment had significantly lower RH (24-25\% vs. 30-43\%), adding further credence 


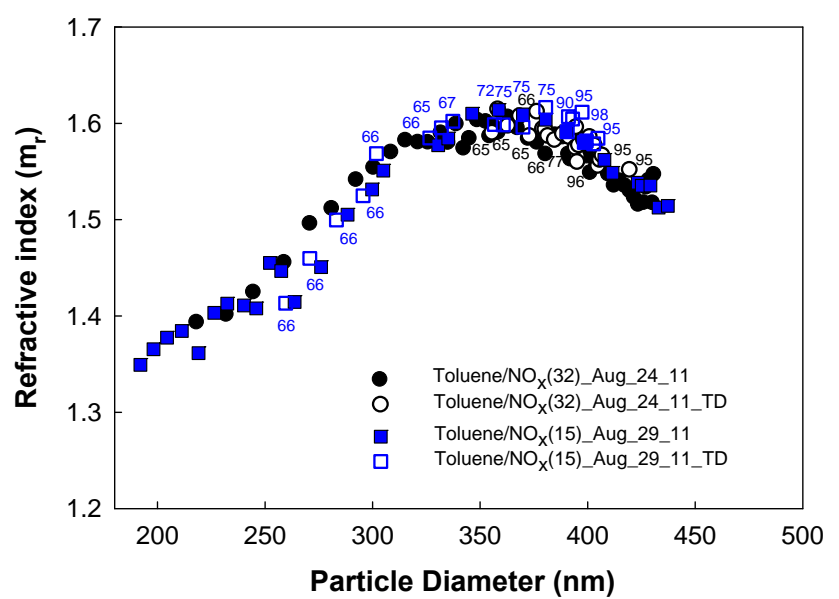

Fig. 3. Retrieved refractive indices for thermodenuded (open symbols) and undenuded (filled symbols) toluene SOA formed by photooxidation of toluene at different $\mathrm{HC} / \mathrm{NO}_{\mathrm{x}}$ ratios. Numbers indicate the TD temperature $\left({ }^{\circ} \mathrm{C}\right)$.

to the notion that increasing $\mathrm{RH}$ increases SOA volatility (above).

\subsection{SOA refractive indices}

Refractive indices for SOA cover a wide range, indicating significant, optically relevant variability in chemical composition. Aerosol chemical composition is expected to depend on the parent hydrocarbon, its oxidation chemistry, the particle mass concentration, size, the temperature, and under longer time scales, potentially in-particle reactions and heterogeneous aging (Kim et al., 2012).

\subsubsection{Photochemically generated SOA}

The photochemical experiments were performed over a range of relative humidities (15-24\%) for which water uptake of larger particles is not expected to change rapidly (e.g., Mikhailov et al., 2009). The amount of water uptake may change considerably, however, as the particles grow (VanReken et al., 2005; Varutbangkul et al., 2006). Fresher/smaller particles are expected to contain a higher fraction of low volatility highly oxidized, hygroscopic compounds, while older/larger particles may contain less hygroscopic, higher volatility condensing species and/or oligomers (Chhabra et al., 2011; Varutbangkul et al., 2006). Temperatures span a moderate range $\left(33-39^{\circ} \mathrm{C}\right)$ with the exception of two experiments with higher temperatures (26 August, $2 \mathrm{Au}-$ gust), but this does not appear to have a pronounced effect on $m_{\mathrm{r}}$ and MFR (Figs. 2 and 4).

\section{Toluene SOA}

Figure 3 shows $m_{\mathrm{r}}$ 's of undenuded (filled symbols) and thermodenuded (open symbols) particles as a function of diam- eter for photochemically generated toluene SOA under different $\mathrm{HC} / \mathrm{NO}_{\mathrm{x}}$ ratios. The numbers denote the TD temperature. Consistent with previous studies (Kim et al., 2010; Nakayama et al., 2010, 2013), the freshest toluene SOAs have $m_{\mathrm{r}}$ 's as low as 1.35 . These grew to 1.61 as the experiments progressed, and then decreased somewhat toward the end of the experiments. The value of 1.61 is significantly higher than any $m_{\mathrm{r}}$ 's observed for SOA generated from any biogenic HC, but it is consistent with our earlier results (Kim et al., 2010, 2012). The same increasing behavior of $m_{\mathrm{r}}$ 's was observed at Nakayama et al. (2013) as increasing O/C ratios of the SOA and diameter at $532 \mathrm{~nm}$, suggesting $\mathrm{O} / \mathrm{C}$ ratios of toluene SOA continuously increase as particles grow, and this eventually results in an increase in $m_{\mathrm{r}}$ 's. Continuously increasing $\mathrm{O} / \mathrm{C}$ ratios of photochemically generated toluene/or single ring aromatic SOA has also been observed in previous chamber studies (Chhabra et al., 2010). Nakayama et al. (2013) also found higher $m_{\mathrm{r}}$ 's of toluene SOA than other biogenic SOA (e.g., $\alpha$-pinene SOA), suggesting this is probably because of the higher $\mathrm{O} / \mathrm{C}$ ratio of the toluene SOAs $(\mathrm{O} / \mathrm{C}=0.64-0.73$, Nakayama et al., 2013) than those for the $\alpha$-pinene SOAs (O/C $=0.43-0.47)$ (Nakayama et al., 2012). Very recently, Lambe et al. (2013) also showed that $m_{\mathrm{r}}$ 's (at $\lambda=404,532 \mathrm{~nm}$ ) of SOA generated from aromatic precursors were higher than those for biogenic precursors. Further, the study of Lambe et al. (2013) showed a decreasing trend of $m_{\mathrm{r}}$ 's with $\mathrm{O} / \mathrm{C}$ ratio, the opposite of the Nakayama et al. (2013) results. The difference could arise from the fact that Lambe et al. (2013) investigated $m_{\mathrm{r}}$ 's for wider ranges of O/C ratios (0.4-1.3) than did Nakayama et al. (2013).

We note that there is no evidence of significant absorption at $532 \mathrm{~nm}$ by toluene SOA. GA retrievals (which can provide only a rough estimate of absorption) return imaginary components below our rough detection limit of $10^{-4}$. Barkey et al. (2011) and Nakayama et al. (2010) also reported a negligible absorption ( $\left.m_{\mathrm{i}}=0.0002-0.0017\right)$ at $532 \mathrm{~nm}$.

Toluene SOA refractive indices were virtually unchanged by heating up to $\sim 98^{\circ} \mathrm{C}$ (Fig. 3), as might be expected given the particles exhibited no evaporation (above), and suggesting heating does not significantly change chemical composition.

\section{Limonene and $\alpha$-pinene photochemical SOA}

Figure 4 shows $m_{\mathrm{r}}$ 's of photochemically generated limonene and $\alpha$-pinene SOA generated using different $\mathrm{HC} / \mathrm{NO}_{\mathrm{x}}$ ratios. Figure $\mathrm{S} 4$ directly compares the (undenuded) $m_{\mathrm{r}}$ data for limonene and $\alpha$-pinene with Kim et al. (2012); the two data sets are in good agreement. The current data set extends the size range for limonene aerosol, and shows that as particles grow above $\sim 320 \mathrm{~nm}, m_{\mathrm{r}}$ 's start to decrease with increasing size. This has been previously observed for $\alpha$ - and $\beta$-pinene and toluene (Kim et al., 2010, 2012), but not limonene. We note that $\mathrm{HC} / \mathrm{NO}_{\mathrm{x}}$ ratio is a controlling factor for particle size (Kim et al., 2012); as $\mathrm{HC} / \mathrm{NO}_{\mathrm{x}}$ ratios decrease (e.g., 

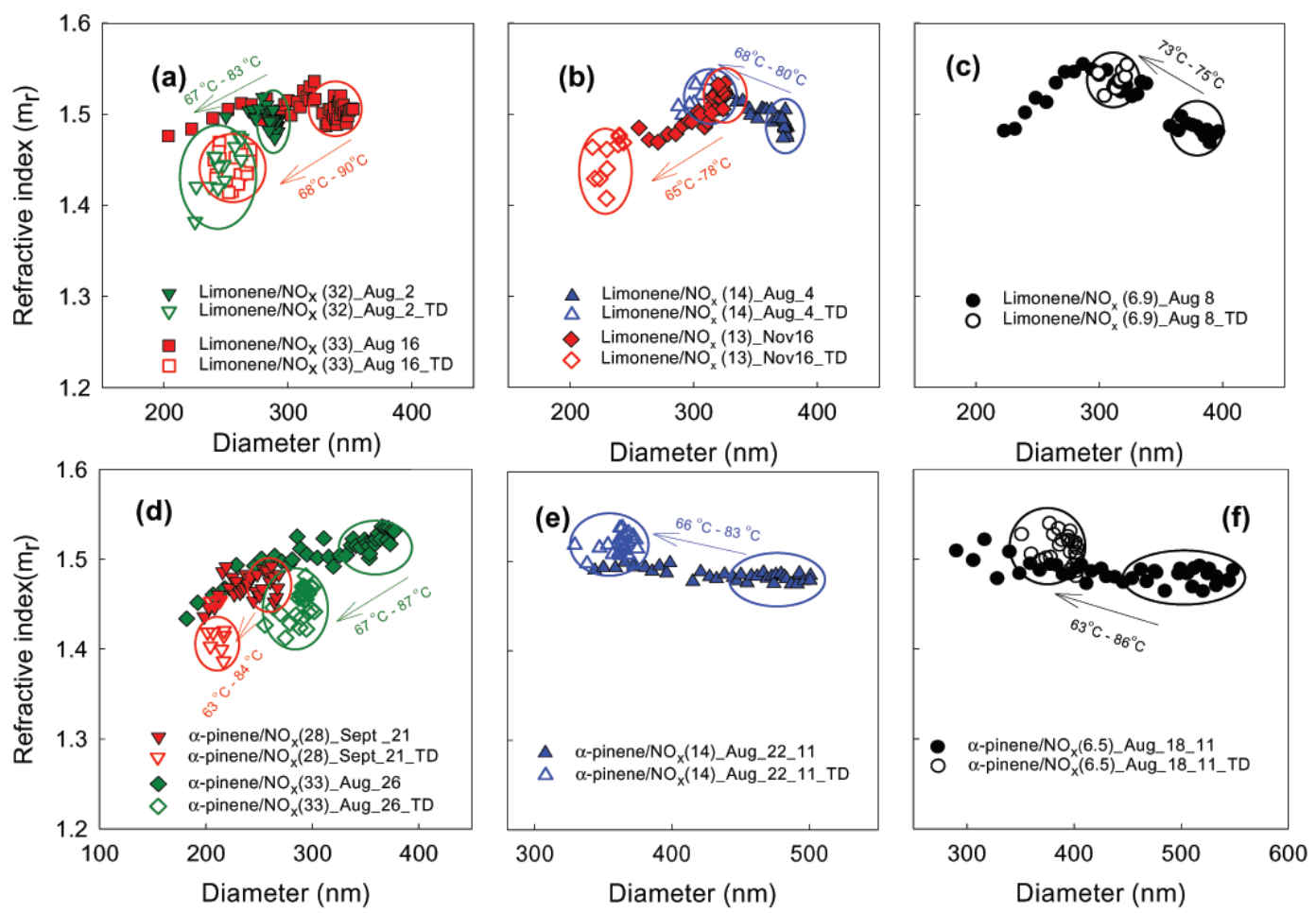

Fig. 4. Retrieved refractive indices for thermodenuded (open symbols) and undenuded (filled symbols) SOA formed by photooxidation of limonene $(\mathbf{a}-\mathbf{c})$ and $\alpha$-pinene $(\mathbf{d}-\mathbf{f})$ at different $\mathrm{HC} / \mathrm{NO}_{\mathrm{x}}$ ratios. TD temperatures are indicated.

the middle and right panels in Fig. 4), the size ranges of the particles increase for both limonene and $\alpha$-pinene, with the exceptions of limonene on 16 November and $\alpha$-pinene on 21 September. The smaller size ranges of these experiments seem to be influenced by the lower temperatures and light intensities associated with their later dates (Table 1); however their $m_{\mathrm{r}}$ values are consistent with the same size particles in other experiments. For limonene SOA (Fig. 4a-c), filled symbols (undenuded particles) show that $m_{\mathrm{r}}$ 's increase from 1.47 to 1.55 as the particle diameters increase up to $\sim 320 \mathrm{~nm}$. After this, they drop off somewhat (for $\mathrm{HC} / \mathrm{NO}_{\mathrm{x}}$ $=6.9-13$, Fig. $4 \mathrm{~b}$ and c). $\alpha$-Pinene (Fig. $4 \mathrm{~d}-\mathrm{f}$,) shows the same $m_{\mathrm{r}}$ trend with diameter; refractive indices increase from 1.43 to 1.54 as the diameters of particles increase when the $\mathrm{HC} / \mathrm{NO}_{\mathrm{x}}$ ratio was $28-33$ (Fig. 4d). For the lower $\mathrm{HC} / \mathrm{NO}_{\mathrm{x}}$ ratio experiments, $m_{\mathrm{r}}$ 's drop off somewhat as particles grow above $370 \mathrm{~nm}$ (Figs. 4e and 4f). We have consistently observed that the smallest, newest particles have significantly lower refractive indices than larger particles. $\mathrm{HC} / \mathrm{NO}_{\mathrm{x}}$ ratiodependent differences in higher and lower volatility condensing species and their contributions relative to one another appear to contribute to determine size distributions as well as the $m_{\mathrm{r}}$ 's. Decreasing $m_{\mathrm{r}}$ 's for larger particles toward the end of the experiments may result from shifts in the composition of the condensing material, or possibly changes in particle composition caused by heterogeneous or in-particle reactions (i.e., aging).
For both limonene and $\alpha$-pinene SOA generated at high or intermediate $\mathrm{HC} / \mathrm{NO}_{\mathrm{x}}$ ratios, the TD changes their $m_{\mathrm{r}}$, in most cases to that of the corresponding particle size earlier in the experiment (Fig. 4, indicated with ovals and arrows). For example, for limonene $\mathrm{HC} / \mathrm{NO}_{\mathrm{x}}=14$ (Fig. $4 \mathrm{~b}$ and c), after heating, $\sim 370 \mathrm{~nm}$ particles were reduced by $50-80 \mathrm{~nm}$ while their $m_{\mathrm{r}}$ 's were increased by about 0.03 from 1.481.5 to $1.5-1.54$. For $\mathrm{HC} / \mathrm{NO}_{\mathrm{x}}=13$, the $\sim 320 \mathrm{~nm}$ particles shrank by $80-100 \mathrm{~nm}$ while their $m_{\mathrm{r}}$ 's decreased from 1.511.53 to 1.4-1.48. Both cases match the values for this size of SOA before heating. $\alpha$-Pinene SOA (Fig. 4e and f) behaves similarly. While the observed TD behavior is consistent with a model for aerosol growth in which more volatile species are deposited on lower volatility species as the experiments progress (Cappa and Wilson, 2011, and references therein), other explanations such as reversible in-particle reactions and reversible internal mixing are also quite plausible.

In contrast to mid- and high $\mathrm{NO}_{\mathrm{x}}$ photooxidations, for both limonene and $\alpha$-pinene at low $\mathrm{NO}_{\mathrm{x}}\left(\mathrm{HC} / \mathrm{NO}_{\mathrm{x}}=33\right)$, thermodenuding produces particles with $m_{\mathrm{r}}$ 's that are lower than those of the same size earlier in the experiment (Fig. 4a and d). For limonene $\mathrm{HC} / \mathrm{NO}_{\mathrm{x}}=32-33$ (Fig. 4a) SOA, heating reduced the size of limonene SOA by $30-100 \mathrm{~nm}$ with concomitant changes in the $m_{\mathrm{r}}$ 's from $1.48-1.52$ to $\sim 1.38$ 1.48. $\alpha$-Pinene SOA from $\mathrm{HC} / \mathrm{NO}_{\mathrm{x}}=28-33$ (26 August and 21 September, Fig. 4d) behaves similarly. The $m_{\mathrm{r}}$ values for the denuded particles are lower than those of the same size 

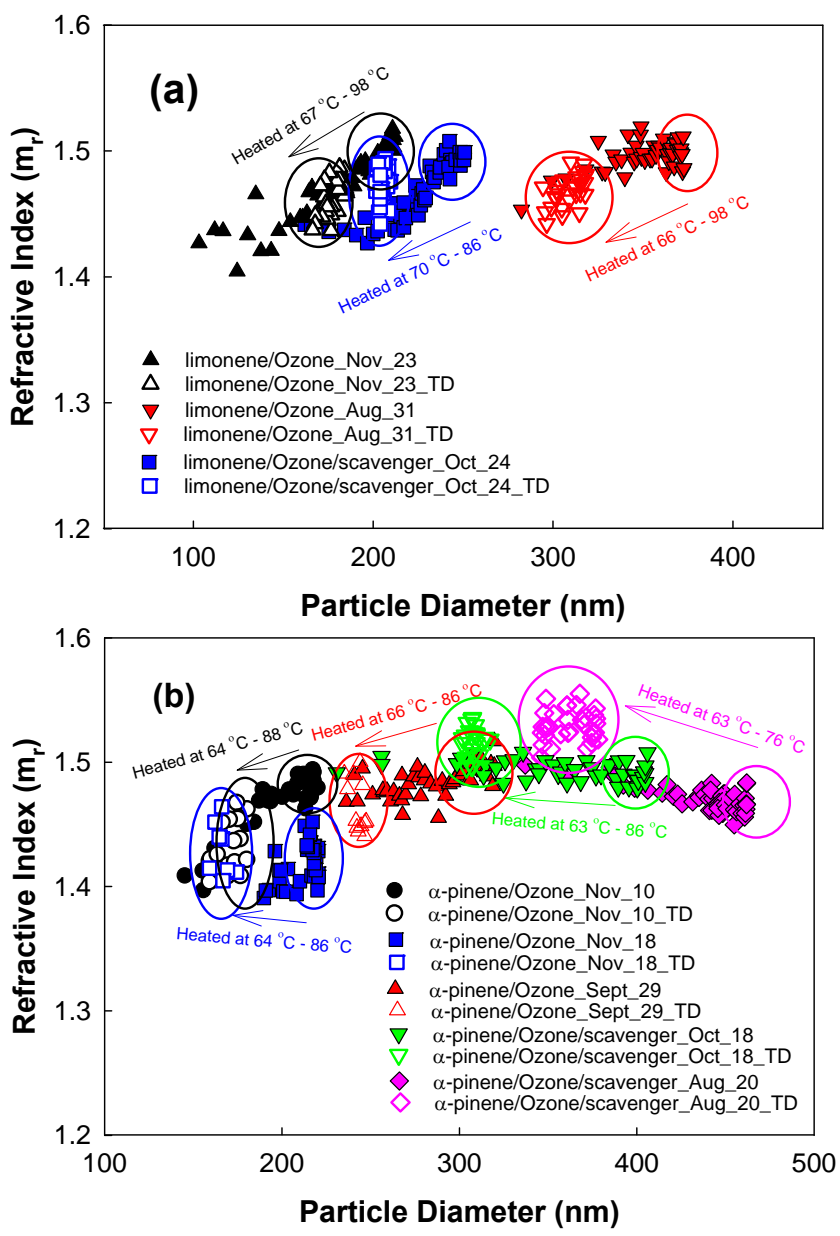

Fig. 5. Retrieved refractive indices for thermodenuded (open symbols) and undenuded (filled symbols) SOA formed by ozonolysis of (a) $\alpha$-pinene and (b) limonene with and without scavenger.

undenuded particles by $0.03-0.06$. The results suggest different chemical composition of SOA generated under low $\mathrm{NO}_{\mathrm{x}}$ conditions. Several studies have investigated chemical composition of SOA generated at high and low $\mathrm{NO}_{\mathrm{x}}$. The most striking differences are in formation of organic nitrate $\left(\mathrm{R}-\mathrm{ONO}_{2}\right)$ and hydroperoxide $(\mathrm{ROOH})$; at high $\mathrm{NO}_{\mathrm{x}}$, organic nitrate $\left(\mathrm{R}-\mathrm{ONO}_{2}\right)$ formation is favorable, whereas at low $\mathrm{NO}_{\mathrm{x}}$ conditions, hydroperoxide $(\mathrm{ROOH})$ is more dominant (Kroll and Seinfeld (2008) and references therein). Recently, Eddingsaas et al. (2012) showed that for $\alpha$-pinene $\mathrm{SOA}$, pinonic and pinic acid were only found under low $\mathrm{NO}_{\mathrm{x}}$ conditions, although the total concentrations of organic acid are similar at all $\mathrm{HC} / \mathrm{NO}_{\mathrm{x}}$ ratios. While the refractive index is strongly correlated with changing chemical composition over the course of a photooxidation experiment (Kim et al., 2013), this relationship is in need of further study.

\subsubsection{Ozonolysis}

Figure 5 shows refractive indices of SOA generated from $\alpha$-pinene and limonene ozonolysis with and without an $\mathrm{OH}$ scavenger. As particles grow, $m_{\mathrm{r}}$ 's increase from about 1.39 to 1.52. The $\mathrm{OH}$ scavenger had no discernible effect on $m_{\mathrm{r}}$ 's for either terpene, consistent with results of Kim et al. (2010) for $\alpha$-pinene SOA at somewhat higher mass concentrations. The November $18 \alpha$-pinene data have lower refractive indices (1.39-1.45) than the other experiments, a phenomenon we consistently observe for particles generated at lower temperatures (Kim et al., 2010, 2013). Several other researchers have noted significant differences in chemical composition of $\alpha$-pinene SOA generated at different temperatures, including in the range studied here (Warren et al., 2009; Wang et al., 2011; Salo et al., 2012).

For all limonene ozonolysis SOA, as well as $\alpha$ pinene $/ \mathrm{O}_{3} /$ no $\mathrm{OH}$ scavenger, retrieved $m_{\mathrm{r}}$ 's for the thermodenuded particles match the same sized particles before heating (Fig. 5). However, for $\alpha$-pinene SOA with $\mathrm{OH}$ scavenger (Fig. 5b, 20 August and 18 October), $m_{\mathrm{r}}$ 's of thermodenuded SOA (TD temperature of $65-85^{\circ} \mathrm{C}$ ) were slightly higher than $m_{\mathrm{r}}$ 's of the undenuded particles (1.49-1.55 compared to 1.48-1.5). This suggests that although the MFR is independent of the experimental conditions (Sect. 3.3.2 and Fig. 3), the chemical composition of these particles after evaporation is different. Consistent with this, Cappa and Wilson (2011) and Huffman et al. (2009) observed mass spectra of SOA generated from $\alpha$-pinene/ozone/no OH scavenger do not change despite significant mass loss due to evaporation over the temperature range of $23-170^{\circ} \mathrm{C}$. However, for $\alpha$ pinene $/ \mathrm{O}_{3}$ with $\mathrm{OH}$ scavenger SOA, Kostenidou et al. (2009) showed that the fraction of $\mathrm{CO}_{2}^{+}(\mathrm{m} / z$ 44) of SOA increased by $37.5 \%$ when particles are denuded at $60-70^{\circ} \mathrm{C}$. However, given the differences in particle generation conditions (e.g., tube vs. chamber, oxidation time) between studies, there may be explanations other than the presence of $\mathrm{OH}$ scavenger. More controlled experiments relating refractive index with chemical composition are needed.

\section{Atmospheric implications}

Changing the refractive index from 1.4 to 1.5 decreases the asymmetry factor by 0.067 , which in turn changes radiative forcing by at least $12-19 \%$ for non-absorbing aerosol (Andrews et al., 2006; Kim et al., 2010; Marshall et al., 1995). Aerosol extinction in the atmosphere is a function of several parameters, including size distribution, mass concentration, and the mixing state of particles, and the optical properties of the components, as demonstrated by Yu et al. (2012). For sizes smaller than about $0.4 \mu \mathrm{m}$, extinction is much more sensitive to size than refractive index or other properties. Nevertheless, for particles of fixed size in the 0.3$0.4 \mu \mathrm{m}$ size range, Yu et al. (2012) found that changing the 


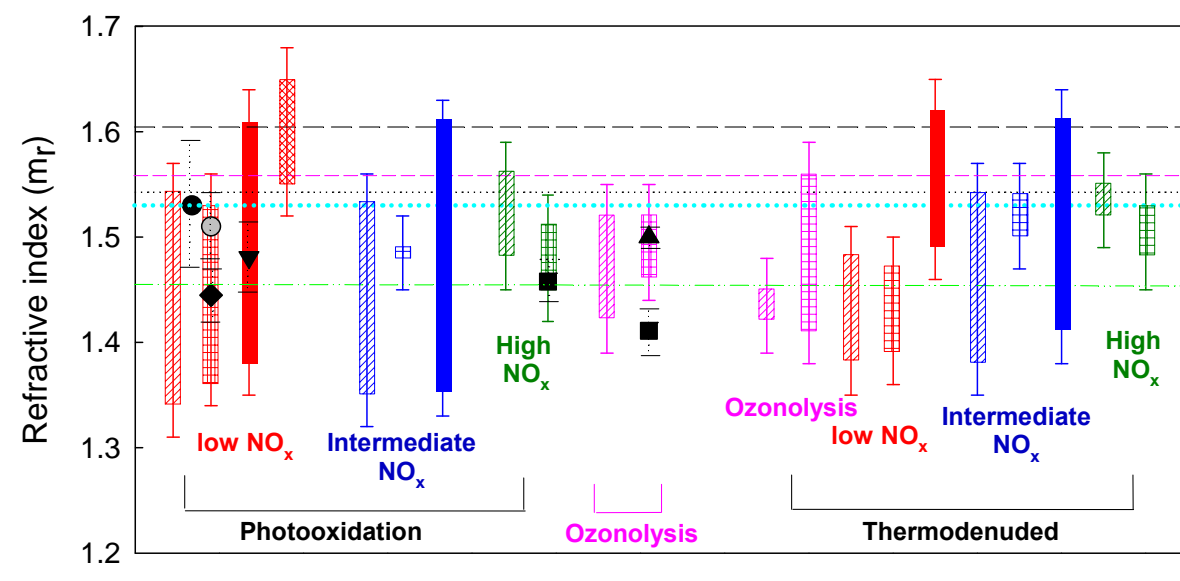

Types of SOA

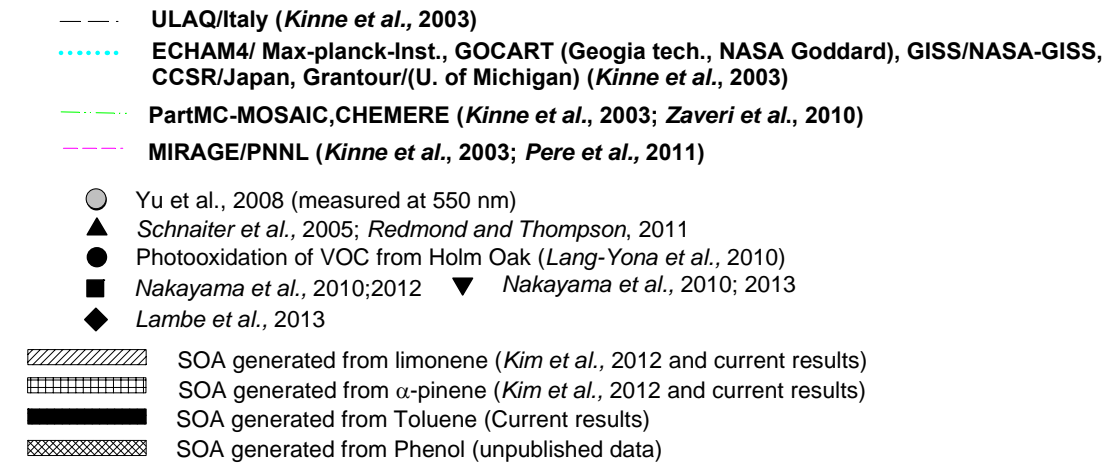

Fig. 6. Comparisons of refractive indices of thermodenuded and undenuded SOA studied in previous studies (Kim et al., 2010, 2012). Ranges of refractive index for each SOA result from changing chemical composition as the particles are growing or aging; error bars are \pm 0.03 for Kim et al. studies. This is the absolute error for the $m_{\mathrm{r}}$ retrievals. Errors for Barkey et al. (2007) were \pm 0.15 ; Lang-Yona et al. (2010) \pm 0.05 ; Nakayama et al. (2010) \pm 0.04 ; Redmond and Thompson (2011) \pm 0.04 ; and Yu et al. (2008) \pm 0.03 uncertainties, respectively. Uncertainties for the Schnaiter et al. (2005) study are not available. Horizontal lines indicate SOA or organic aerosol refractive indices assumed by different current aerosol/climate models. Black and grey symbols represent literature values of SOA generated using the same hydrocarbon and oxidation chemistries denoted in the figure. The phenol data are not published and generated at $\mathrm{HC} / \mathrm{NO}_{\mathrm{x}}=35-41$. $\mathrm{HC} / \mathrm{NO}_{x}$ ratios are 20-33, 13-19 and 6.3-11 for low, intermediate and high $\mathrm{NO}_{\mathrm{x}}$, respectively.

refractive index from 1.33 to 1.53 changed aerosol extinction by about a factor of 2 , for both particles with black carbon cores and particles without a core. Figure 6 shows the ranges of $m_{\mathrm{r}}$ 's determined from chamber studies by our group together with results from the literature. Horizontal lines indicate the values used in coupled models with detailed treatment of aerosols (Kinne et al., 2003; Pere et al., 2011; Zaveri et al., 2010). The wide ranges for each experiment result from the changing chemical composition as the particles are growing and aging. It is clear that SOA $m_{\mathrm{r}}$ 's are highly variable and dependent on a number of factors, including $\mathrm{HC} / \mathrm{NO}_{\mathrm{x}}$ ratios, mass, size, aging and temperature, which determine the chemical composition of SOA. In an effort to retrieve the $m_{\mathrm{r}}$ 's of SOA that may better resemble ambient aerosol, this work explores the effect of parent hydrocarbon ( $\alpha$-pinene, limonene and toluene) and oxidation chemistry (with and without $\mathrm{OH}$ scavenger for ozonolysis, different $\mathrm{HC} / \mathrm{NO}_{\mathrm{x}}$ ratios for photooxidation) on the volatil- ity and related refractive indices of SOA, accomplished by removing high volatility components using a thermodenuder. The above factors as well as a minor contribution from RH and temperature appear to determine the volatility as well as related $m_{\mathrm{r}}$ 's of the SOA.

More work is clearly needed before SOA optical properties are well understood. Based on results to date, however, some recommendations can be made. From a global perspective, biogenic aerosol is generated most commonly under low $\mathrm{NO}_{\mathrm{x}}$ conditions. Therefore, the median $m_{\mathrm{r}}$ 's of $\alpha, \beta$ and limonene generated at low $\mathrm{NO}_{\mathrm{x}}, 1.44$, may be the best values to use. The refractive index of anthropogenic SOA (toluene and phenol) is generally higher, suggesting a representative value of around 1.55. It should be noted that nonaromatic anthropogenic compounds may contribute substantially to SOA in urban areas (Robinson et al., 2007), suggesting that more work is needed to establish representative values for urban SOA. 


\section{Supplementary material related to this article is available online at: http://www.atmos-chem-phys.net/13/ 7711/2013/acp-13-7711-2013-supplement.pdf.}

Acknowledgements. H. Kim gratefully acknowledges the support of a UCLA dissertation year fellowship. The authors are indebted to Brian Barkey (UCLA), who is responsible for the design and development of the polar nephelometer as well as the refractive index retrieval algorithms and ongoing helpful discussions. The authors also appreciate assistance with experiments from Wonsik Choi and Michelle Kuang.

Edited by: D. Topping

\section{References}

Andrews, E., Sheridan, P. J., Fiebig, M., McComiskey, A., Ogren, J. A., Arnott, P., Covert, D., Elleman, R., Gasparini, R., Collins, D., Jonsson, H., Schmid, B., and Wang, J.: Comparison of methods for deriving aerosol asymmetry parameter, J. Geophys. ResAtmos., 111, D05s04 10.1029/2004jd005734, 2006.

Barkey, B., Paulson, S. E., and Chung, A.: Genetic algorithm inversion of dual polarization polar nephelometer data to determine aerosol refractive index, Aerosol Sci. Technol., 41, 751760, doi:10.1080/02786820701432640, 2007.

Barkey, B., Paulson, S. E., and Liou, K. N.: Polar nephelometer: Design and measurements, Light Scattering Reviews, 6, 3-37, 2011.

Cappa, C. D. and Wilson, K. R.: Evolution of organic aerosol mass spectra upon heating: Implications for oa phase and partitioning behavior, Atmos. Chem. Phys., 11, 1895-1911, doi:10.5194/acp11-1895-2011, 2011.

Chhabra, P. S., Flagan, R. C., and Seinfeld, J. H.: Elemental analysis of chamber organic aerosol using an aerodyne high-resolution aerosol mass spectrometer, Atmos. Chem. Phys., 10, 4111-4131, doi:10.5194/acp-10-4111-2010, 2010

Chhabra, P. S., Ng, N. L., Canagaratna, M. R., Corrigan, A. L., Russell, L. M., Worsnop, D. R., Flagan, R. C., and Seinfeld, J. H.: Elemental composition and oxidation of chamber organic aerosol, Atmos. Chem. Phys., 11, 8827-8845, doi:10.5194/acp-11-88272011, 2011.

Chung, A., Lall, A. A., and Paulson, S. E.: Particulate emissions by a small non-road diesel engine: Biodiesel and diesel characterization and mass measurements using the extended idealized aggregates theory, Atmos. Environ., 42, 2129-2140, doi:10.1016/j.atmosenv.2007.11.050, 2008.

Eddingsaas, N. C., Loza, C. L., Yee, L. D., Chan, M., Schilling, K. A., Chhabra, P. S., Seinfeld, J. H., and Wennberg, P. O.: A-pinene photooxidation under controlled chemical conditions - part 2: Soa yield and composition in low- and high-no $\mathrm{x}_{\mathrm{x}}$ environments, Atmos. Chem. Phys., 12, 7413-7427, doi:10.5194/acp-12-74132012, 2012.

Griffin, R. J., Cocker, D. R., Flagan, R. C., and Seinfeld, J. H.: Organic aerosol formation from the oxidation of biogenic hydrocarbons, J. Geophys. Res.-Atmos., 104, 3555-3567, 1999.
Hallquist, M., Wenger, J. C., Baltensperger, U., Rudich, Y., Simpson, D., Claeys, M., Dommen, J., Donahue, N. M., George, C., Goldstein, A. H., Hamilton, J. F., Herrmann, H., Hoffmann, T., Iinuma, Y., Jang, M., Jenkin, M. E., Jimenez, J. L., Kiendler-Scharr, A., Maenhaut, W., McFiggans, G., Mentel, Th. F., Monod, A., Prévôt, A. S. H., Seinfeld, J. H., Surratt, J. D., Szmigielski, R., and Wildt, J.: The formation, properties and impact of secondary organic aerosol: current and emerging issues, Atmos. Chem. Phys., 9, 5155-5236, doi:10.5194/acp-9-51552009, 2009.

Huffman, J. A., Docherty, K. S., Mohr, C., Cubison, M. J., U1brich, I. M., Ziemann, P. J., Onasch, T. B., and Jimenez, J. L.: Chemically-resolved volatility measurements of organic aerosol from different sources, Environ. Sci. Technol., 43, 5351-5357, doi:10.1021/es803539d, 2009.

Jonsson, A. M., Hallquist, M., and Saathoff, H.: Volatility of secondary organic aerosols from the ozone initiated oxidation of alpha-pinene and limonene, J. Aerosol. Sci., 38, 843-852, doi:10.1016/j.jaerosci.2007.06.008, 2007.

Kanakidou, M., Seinfeld, J. H., Pandis, S. N., Barnes, I., Dentener, F. J., Facchini, M. C., Van Dingenen, R., Ervens, B., Nenes, A., Nielsen, C. J., Swietlicki, E., Putaud, J. P., Balkanski, Y., Fuzzi, S., Horth, J., Moortgat, G. K., Winterhalter, R., Myhre, C. E. L., Tsigaridis, K., Vignati, E., Stephanou, E. G., and Wilson, J.: Organic aerosol and global climate modelling: a review, Atmos. Chem. Phys., 5, 1053-1123, doi:10.5194/acp-5-1053-2005, 2005.

Kim, H., Barkey, B., and Paulson, S. E.: Real refractive indices of alpha- and beta-pinene and toluene secondary organic aerosols generated from ozonolysis and photo-oxidation, J. Geophys. Res.-Atmos., 115, D24212 doi:10.1029/2010jd014549, 2010.

Kim, H., Barkey, B., and Paulson, S. E.: Real refractive indices and formation yields of secondary organic aerosol generated from photooxidation of limonene and $\alpha$-pinene: The effect of the hc/nox ratio, J. Phys. Chem. A, 116, 6059-6067, 2012.

Kinne, S., Lohmann, U., Feichter, J., Schulz, M., Timmreck, C., Ghan, S., Easter, R., Chin, M., Ginoux, P., Takemura, T., Tegen, I., Koch, D., Herzog, M., Penner, J., Pitari, G., Holben, B., Eck, T., Smirnov, A., Dubovik, O., Slutsker, I., Tanre, D., Torres, O., Mishchenko, M., Geogdzhayev, I., Chu, D. A., and Kaufman, Y.: Monthly averages of aerosol properties: A global comparison among models, satellite data, and aeronet ground data, J. Geophys. Res.-Atmos., 108, 4634, doi:10.1029/2001jd001253, 2003.

Kostenidou, E., Lee, B. H., Engelhart, G. J., Pierce, J. R., and Pandis, S. N.: Mass spectra deconvolution of low, medium, and high volatility biogenic secondary organic aerosol, Environ. Sci. Technol., 43, 4884-4889, doi:10.1021/es803676g, 2009.

Kroll, J. H. and Seinfeld, J. H.: Chemistry of secondary organic aerosol: Formation and evolution of low-volatility organics in the atmosphere, Atmos. Environ., 42, 3593-3624, doi:10.1016/j.atmosenv.2008.01.003, 2008.

Lambe, A. T., Cappa, C. D., Massoli, P., Onasch, T. B., Forestieri, S. D., Martin, A. T., Cummings, M. J., Croasdale, D. R., Brune, W. H., Worsnop, D. R., and Davidovits, P.: Relationship between oxidation level and optical properties of secondary organic aerosol, Environ. Sci. Technol., 47, 6349-6357, doi:10.1021/es401043j, 2013.

Lang-Yona, N., Rudich, Y., Mentel, T. F., Bohne, A., Buchholz, A., Kiendler-Scharr, A., Kleist, E., Spindler, C., Tillmann, R., 
and Wildt, J.: The chemical and microphysical properties of secondary organic aerosols from holm oak emissions, Atmos. Chem. Phys., 10, 7253-7265, doi:10.5194/acp-10-7253-2010, 2010.

Lee, B. H., Pierce, J. R., Engelhart, G. J., and Pandis, S. N.: Volatility of secondary organic aerosol from the ozonolysis of monoterpenes, Atmos. Environ., 45, 2443-2452, doi:10.1016/j.atmosenv.2011.02.004, 2011.

Marshall, S. F., Covert, D. S., and Charlson, R. J.: Realationship between asymmetry parameter and hemispheric backscatter ratio - implications for climate forcing by aerosols, Appl. Opt., 34, 6306-6311, 1995.

Matsunaga, A. and Ziemann, P. J.: Gas-wall partitioning of organic compounds in a teflon film chamber and potential effects on reaction product and aerosol yield measurements, Aerosol Sci. Technol., 44, 881-892, doi:10.1080/02786826.2010.501044, 2010.

Mikhailov, E., Vlasenko, S., Martin, S. T., Koop, T., and Pöschl, U.: Amorphous and crystalline aerosol particles interacting with water vapor: conceptual framework and experimental evidence for restructuring, phase transitions and kinetic limitations, Atmos. Chem. Phys., 9, 9491-9522, doi:10.5194/acp-9-9491-2009, 2009.

Mishchenko, M. I., Cairns, B., Kopp, G., Schueler, C. F., Fafaul, B. A., Hansen, J. E., Hooker, R. J., Itchkawich, T., Maring, H. B., and Travis, L. D.: Accurate monitoring of terrestrial aerosols and total solar irradiance: Introducing the glory mission, Bull. Amer. Meteor. Soc., 88, 677-691, 2007.

Nakayama, T., Matsumi, Y., Sato, K., Imamura, T., Yamazaki, A., and Uchiyama, A.: Laboratory studies on optical properties of secondary organic aerosols generated during the photooxidation of toluene and the ozonolysis of alpha-pinene, J. Geophys. ResAtmos., 115, D24204, doi:10.1029/2010jd014387, 2010.

Nakayama, T., Sato, K., Matsumi, Y., Imamura, T., Yamazaki, A., and Uchiyama, A.: Wavelength and nox dependent complex refractive index of soas generated from the photooxidation of toluene, Atmos. Chem. Phys., 13, 531-545, doi:10.5194/acp-13531-2013, 2013.

Ng, N. L., Kroll, J. H., Keywood, M. D., Bahreini, R., Varutbangkul, V., Flagan, R. C., Seinfeld, J. H., Lee, A., and Goldstein, A. H.: Contribution of first- versus second-generation products to secondary organic aerosols formed in the oxidation of biogenic hydrocarbons, Environ. Sci. Technol., 40, 2283-2297, doi:10.1021/es052269u, 2006.

Ng, N. L., Kroll, J. H., Chan, A. W. H., Chhabra, P. S., Flagan, R. C., and Seinfeld, J. H.: Secondary organic aerosol formation from m-xylene, toluene, and benzene, Atmos. Chem. Phys., 7, 3909-3922, doi:10.5194/acp-7-3909-2007, 2007.

Paulson, S. E., Sen, A. D., Liu, P., Fenske, J. D., and Fox, M. J.: Evidence for formation of oh radicals from the reaction of $0-3$ with alkenes in the gas phase, Geophys. Res. Lett., 24, 3193 3196, doi:10.1029/97g103163, 1997.

Pere, J. C., Mallet, M., Pont, V., and Bessagnet, B.: Impact of aerosol direct radiative forcing on the radiative budget, surface heat fluxes, and atmospheric dynamics during the heat wave of summer 2003 over western europe: A modeling study, J. Geophys. Res-Atmos., 116, D2311910, doi:1029/2011jd016240, 2011.
Presto, A. A., Hartz, K. E. H., and Donahue, N. M.: Secondary organic aerosol production from terpene ozonolysis, 2. Effect of nox concentration, Environ. Sci. Technol., 39, 7046-7054, doi:10.1021/es050400s, 2005.

Redmond, H. and Thompson, J. E.: Evaluation of a quantitative structure-property relationship (QSPR) for predicting mid-visible refractive index of secondary organic aerosol (SOA), Phys. Chem. Chem. Phys., 13, 6872-6882, doi:10.1039/C0CP02270E, 2011.

Robinson, A. L., Donahue, N. M., Shrivastava, M. K., Weitkamp, E. A., Sage, A. M., Grieshop, A. P., Lane, T. E., Pierce, J. R., and Pandis, S. N.: Rethinking organic aerosols: Semivolatile emissions and photochemical aging, Science, 315, 1259-1262, doi:10.1126/science.1133061, 2007.

Saathoff, H., Naumann, K.-H., Möhler, O., Jonsson, Å. M., Hallquist, M., Kiendler-Scharr, A., Mentel, Th. F., Tillmann, R., and Schurath, U.: Temperature dependence of yields of secondary organic aerosols from the ozonolysis of $\alpha$-pinene and limonene, Atmos. Chem. Phys., 9, 1551-1577, doi:10.5194/acp-9-15512009, 2009.

Saleh, R., Shihadeh, A., and Khlystov, A.: On transport phenomena and equilibration time scales in thermodenuders, Atmos. Meas. Tech., 4, 571-581, doi:10.5194/amt-4-571-2011, 2011.

Salo, K., Hallquist, M., Jonsson, A. M., Saathoff, H., Naumann, K. H., Spindler, C., Tillmann, R., Fuchs, H., Bohn, B., Rubach, F., Mentel, T. F., Muller, L., Reinnig, M., Hoffmann, T., and Donahue, N. M.: Volatility of secondary organic aerosol during oh radical induced ageing, Atmos. Chem. Phys., 11, 11055-11067, doi:10.5194/acp-11-11055-2011, 2012.

Schnaiter, M., Linke, C., Mohler, O., Naumann, K. H., Saathoff, H., Wagner, R., Schurath, U., and Wehner, B.: Absorption amplification of black carbon internally mixed with secondary organic aerosol, J. Geophys. Res.-Atmos., 110, 11, D19204, doi:10.1029/2005jd006046, 2005.

VanReken, T. M., Ng, N. L., Flagan, R. C., and Seinfeld, J. H.: Cloud condensation nucleus activation properties of biogenic secondary organic aerosol, J. Geophys. Res.-Atmos., 110, 9, D07206, doi:10.1029/2004jd005465, 2005.

Varutbangkul, V., Brechtel, F. J., Bahreini, R., Ng, N. L., Keywood, M. D., Kroll, J. H., Flagan, R. C., Seinfeld, J. H., Lee, A., and Goldstein, A. H.: Hygroscopicity of secondary organic aerosols formed by oxidation of cycloalkenes, monoterpenes, sesquiterpenes, and related compounds, Atmos. Chem. Phys., 6, 23672388, doi:10.5194/acp-6-2367-2006, 2006.

Wang, Y., Kim, H., and Paulson, S. E.: Hydrogen peroxide generation from alpha- and beta-pinene and toluene secondary organic aerosols, Atmos. Environ., 45, 3149-3156, doi:10.1016/j.atmosenv.2011.02.060, 2011.

Warren, B., Austin, R. L., and Cocker, D. R.: Temperature dependence of secondary organic aerosol, Atmos. Environ., 43, 35483555, doi:10.1016/j.atmosenv.2009.04.011, 2009.

Yu, F., Luo, G., and Ma, X.: Regional and global modeling of aerosol optical properties with a size, composition, and mixing state resolved particle microphysics model, Atmos. Chem. Phys., 12, 5719-5736, doi:10.5194/acp-12-5719-2012, 2012. 
Yu, Y., Ezell, M. J., Zelenyuk, A., Imre, D., Alexander, L., Ortega, J., D’Anna, B., Harmon, C. W., Johnson, S. N., and Finlayson-Pitts, B. J.: Photooxidation of alpha-pinene at high relative humidity in the presence of increasing concentrations of no(x), Atmos. Environ., 42, 5044-5060, doi:10.1016/j.atmosenv.2008.02.026, 2008.
Zaveri, R. A., Barnard, J. C., Easter, R. C., Riemer, N., and West, M.: Particle-resolved simulation of aerosol size, composition, mixing state, and the associated optical and cloud condensation nuclei activation properties in an evolving urban plume, J. Geophys. Res-Atmos., 115, D17210, doi:10.1029/2009jd013616, 2010. 